\title{
RAC1 wt Allele
}

National Cancer Institute

\section{Source}

National Cancer Institute. RAC1 wt Allele. NCI Thesaurus. Code C99664.

Human RAC1 wild-type allele is located in the vicinity of 7p22 and is approximately $29 \mathrm{~kb}$ in length. This allele, which encodes ras-related C3 botulinum toxin substrate 1 protein, plays a role in cell motility, microfilament organization and signaling. 